\title{
PENILAIAN KECURANGAN: PENGALAMAN, PELATIHAN DAN TINDAKAN SUPERVISI
}

\author{
Michael Prasetya Darma \\ Mulyani* \\ Program Studi Akuntansi, Institut Bisnis dan Informatika Kwik Kian Gie, \\ Jl. Yos Sudarso Kav. 87, Jakarta 14350
}

\begin{abstract}
The auditor's inability to detect fraud, is not up to the expectations of financial statement users. Experiences, Training and Supervision Measures are the 3 most important essential components an auditor must have in a fraudulent area..The purpose of this research are to conduct research to prove whether experience, training and supervision actions affect the assessment of fraud.The survey method with questionary used in this reasarch. The object of this research are auditors who worked in one of the big four Accounting Firms in Jakarta. The sampling technique used is purposive sampling. The result of this research shows that the variable of experience, training and supervision actionhave positive influence to the variable of fraud detection.
\end{abstract}

Keyword: Auditor Experience, Training , Supervision Action and Fraud Detection

\begin{abstract}
Abstrak
Kemampuan auditor dalam mendeteksi kecurangan merupakan kemampuan yang erat kaitannya dengan kepercayaan pemakai terhadap kualitas laporan keuangan. Pengalaman,pelatihan dan tindakan supervisi merupakan tiga kemampuan yang harus dimiliki oleh seorang auditor dalam mendeteksi kecurangan.Tujuan dari penelitian ini adalah untuk melakukan pengujian apakah pengalaman, pelatihan serta tindakan supervisi berpengaruh terhadap penilaian kecurangan. Metode penelitian survei melaui kuesioner digunakan dalam penelitian ini.Para Auditor yang bekerja pada salah satu Kantor Akuntan Publik (KAP) big four di Jakarta digunakan sebagai obyek penelitian ini. Teknik pengambilan sampel random sampling digunakan dalam penelitian ini. Hasil penelitian ini menunjukkan bahwa: variabel pengalaman, pelatihan dan tindakan supervisi memiliki pengaruh positif terhadap variabel penilaian kecurangan.
\end{abstract}

Kata Kunci: Pengalaman Auditor, Pelatihan, Tindakan Supervisi dan Pendeteksian Kecurangan

\section{Pendahuluan}

$\mathrm{P}$ erusahaan memerlukan jasa auditor dalam memeriksa laporan keuangan perusahaan. Hal ini bertujuan agar laporan keuangan perusahaan telah memenuhi norma pelaporan keuangan, sehingga dapat digunakan oleh pihak eksternal perusahaan dan pada akhirnya kepercayaan pihak eksternal kepada manajemen perusahaan menjadi meningkat.

Selain memeriksa laporan keuangan, auditor dituntut untuk dapat memeriksa apakah terdapat tindakan kecurangan yang dibuat oleh perusahaan dalam laporan keuangan yang dihasilkan. Dalam proses audit,tidak adanya jaminan kebenaran dari

\footnotetext{
* Alamat kini:Institut Bisnis dan Informatika Kwik Kian Gie, Jln Yos Sudarso Kav. 87 Sunter , Jakarta 14350 Penulis untuk Korespondensi: Telp. (021) 65307062 Ext. 708. E-mail: mulyani@kwikkiangie.ac.id
} 
hasil laporan keuangan. Banyaknya kasus kegagalan auditor dalam menemukan kecurangan telah membuat persepsi masyarakat terhadap auditor menjadi menurun. Oleh karena itu, kompetensi auditor sangat mempengaruhi kepercayaan masyarakat terhadap proses audit laporan keuangan perusahaan.

Salah satu peran auditor ekternal adalah memastikan laporan keuangan tidak mengandung salah saji (misstatement) yang material, baik yang disebabkan oleh kekeliruan maupun yang disebabkan oleh kecurangan (fraud). Menurut standar audit, faktor yang membedakan kekeliruan dan kecurangan adalah tindakan yang mendasarinya, apakah kesalahan pada laporan keuangan terjadi karena tindakan yang disengaja atau tindakan yang tidak disengaja. Peran auditor adalah memeriksa laporan keuangan tersebut sehingga pemakai laporan keuangan akan percaya bahwa laporan keuangan tidak akan menyesatkan.

Kecurangan semakin marak terjadi dengan berbagai cara yang terus berkembang sehingga kemampuan auditor dalam mendeteksi kecurangan juga harus ditingkatkan.Bagaimanapun juga auditor dituntut untuk tetap mampu mendeteksi kecurangan seandainya terjadi kecurangan dalam melaksanakan tugas auditnya. Masalah yang timbul adalah auditor juga memiliki keterbatasan dalam mendeteksi fraud. Keterbatasan yang dimiliki auditor akan menyebabkan kesenjangan atau expectation gap antara pemakai jasa auditor yang berharap agar auditor dapat memberi keyakinan bahwa laporan keuangan yang disajikan tidak mengandung salah saji dan telah mencerminkan keadaan yang sebenarnya.

Banyak contoh tentang kasus kecurangan. Salah satunya, pada tahun 2012 kasus Miller Energy Resources yang melibatkan Kantor Akuntan Publik KPMG dimana KPMG dikenakan denda sebesar $\$ 6,2$ juta oleh SEC, karena kegagalan audit (auditing failure) terhadap Miller Energy Resources yang berdampak pada peningkatan nilai tercatat asetnya secara signifikan sebesar 100 kali lipat dari nilai riilnya di laporan keuangan tahun 2010. Pada kasus Rolls Royce yang melibatkan KPMG dimana KPMG terbukti berperan dalam gagal dalam mendeteksi fraud dalam laporan keuangan Rolls-Royce pada tahun 2013. Perusahaan raksasa penyedia mesin jet terbesar di inggris, Rolls-Royce didenda sebesar $£ 671$ juta (sekitar 11 triliun) atas kasus pemberian suap kepada pejabat eksekutif pemebeli produk Rolls Royce yang berafiliasi di Amerika, Cina, India, Rusia termasuk Indonesia. Denda ini merupakan denda terbesar sepanjang sejarah Serious Fraud Office (SFO) di inggris. Kasus Rolls Royce juga berdampak pada investigasi terhadap KPMG, sebagai auditor Rolls Royce. Pertanyaan publik adalah bagaimana auditor dapat menerbitkan laporan atau opini, nyatanya mereka gagal menemukan sesuatu yang salah di dalam tubuh organisasi yang diauditnya.

Maraknya skandal kecurangan yang terjadi baik di dalam maupun di luar negeri telah memberikan dampak besar kepercayaan publik terhadap profesi akuntan publik. Pertanyaan besar dalam masyarakat adalah mengapa justru semua kasus tersebut melibatkan profesi akuntan publik yang seharusnya mereka menjadi pihak ketiga yang independen yang memberikan jaminan atas relevansi dan keandalan sebuah laporan keuangan. Kecurangan semakin marak terjadi dengan berbagai cara yang terus berkembang sehingga kemampuan auditor dalam mendeteksi kecurangan juga harus ditingkatkan.

Setiap auditor memiliki kemampuan yang berbeda dalam mendeteksi kecurangan disebabkan karena beberapa faktor, misalnya tingkat pengalaman, pelatihan dan tindakan supervisi auditor yang berbeda. Pengalaman memiliki faktor penting dalam penilaian kecurangan, dalam hal ini ialah auditor yang sudah lama mengusut kasus kecurangan dan 
tahu akan tindakan-tindakan yang akan dilakukan. Seorang auditor dengan jam terbang yang tinggi serta biasa menemukan kecurangan dimungkinkan lebih teliti dalam mendeteksi kecurangan dibanding auditor dengan jam terbang yang rendah. Auditor yang berpengalaman adalah auditor yang mampu mendeteksi, memahami dan bahkan mencari penyebab dari munculnya kecurangan-kecurangan tersebut.

Pengalaman, Pelatihan dan Tindakan Supervisi merupakan tiga komponen utama yang sangat penting yang harus dimiliki oleh seorang auditor dalam mendeteksi kecurangan. Noviyani dan Bandi (2002), bahwa auditor yang berpengalaman akan memiliki pengetahuan tentang kekeliruan dan kecurangan yang lebih banyak sehingga akan menghasilkan kinerja yang lebih baik dalam mendeteksi kasuskecurangan dibandingkan dengan auditor yang tidak berpengalaman.

Pengalaman dapat mempengaruhi kemampuan seorang auditor dalam memprediksi kecurangan yang terjadi dalam sebuah perusahaan. Pengalaman menyangkut lamanya bekerja menjadi auditor, banyaknya penugasan yang telah diselesaikan, dan banyaknya jenis perusahaan yang pernah ditangani. Semakin lama seseorang menjadi auditor, semakin banyak penugasan yang ditangani dan semakin banyak jenis perusahaan yang ditangani, maka dapat dikatakan auditor semakin berpengalaman, pengalaman tersebut akan meningkatkan kesadaran auditor jika terjadi kekeliruan dan kecurangan. Auditor yang berpengalaman juga akan lebih paham terkait penyebab kekeliruan yang terjadi, apakah karena murni kesalahan baik manusia atau alat ataukah kekeliruan karena kesengajaan yang berarti fraud. Dari pengalaman, auditor dapat belajar bagaimana cara yang tepat dalam melakukan suatu penilaian atau judgement.

Beberapa penelitian terdahulu terkait pengaruh pengalaman auditor terhadap penilaian kecurangan yang dilakukan oleh beberapa peneliti, misalnya penelitian yang dilakukan Noviyani dan Bandi (2002), Dina Purnamasari dan Erna Hernawati (2013), dan Eko Ferry Anggriawan (2014) menyatakan bahwa adanya hubungan positif antara pengalaman auditor dengan pendeteksian kecurangan.

Pelatihan memiliki peran yang tidak kalah penting dalam melakukan suatu penilaian kecurangan. Guna menunjang profesionalis- menya auditor dalam melaksanakan tugas auditnya harus berpedoman pada standar audit yang ditetapkan oleh Ikatan Akuntan Indonesia (IAI) yakni standar umum, standar pekerjaan lapangan dan standar pelaporan. Standar umum merupakan cerminan kualitas pribadi yang harus dimiliki oleh seorang auditor yang mengharuskan auditor untuk memiliki keahlian dan pelatihan teknis yang cukup dalam melaksanakan prosedur audit. Sedangkan standar pekerjaan lapangan dan standar pelaporan mengatur auditor dalam hal pengumpulan data dan kegiatan lainnya yang dilaksanakan selama melakukan audit serta mewajibkan auditor untuk menyusun suatu laporan atas laporan keuangan yang diauditnya secara keseluruhan. Memiliki pengalaman saja tidaklah cukup jika tidak diimbangi dengan pelatihan yang banyak. Melalui pengetahuan dan pelatihan itulah auditor dapat melaksanakan tugas auditnya dengan baik.

Berdasarkan dari fenomena yang terjadi karena kurangnya pelatihan sehingga terdapat kasus yang menimpa pada Bank Rakyat Indonesia atau BRI di tahun 2009 yang dalam laporan keuangan auditannya melaporkan laba bersih sebesar Rp132 milyar, namun kemudian Kementerian BUMN dan Bapepam menyajikan kembali laporan keuangan tersebut dan menyatakan

keuntungan perusahaan hanya sebesar Rp99,56 miliar, 24,7\% lebih rendah dari laba awal yang semula dilaporkan perusahaan. Auditor KPMG dinyatakan tidak mampu 
mendeteksi kecurangan yang ada dalam laporan keuangan tersebut karena kurangnya pemahaman kasus yang terjadi pada Bank Rakyat Indonesia.

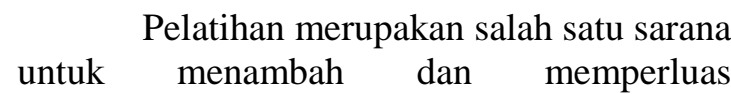
pengetahuan serta mengasah keterampilan sebagai seorang auditor yang professional. Dengan memiliki keterampilan yang lebih matang maka seorang auditor dapat melaksanakan tugas audit dengan lebih teliti dan sesuai dengan standar audit.

Karim dan Lhaksmi (2008) mendefinisikan pelatihan sebagai suatu latihan kecakapan, kemahiran, ketangkasan dalam melaksanakan tugas. Selanjutnya dinyatakan pula bahwa pelatihan audit dirancang untuk meningkatkan kompetensi auditor dalam melakukan audit.Haryanti (2013) menyatakan bahwa pelatihan memiliki fungsi-fungsi edukatif, administratif dan profesional. Fungsi edukatif mengacu pada peningkatan kemampuan profesional, kepribadian, dedikasi dan loyalitas pada organisasi. Fungsi administrasi mengacu pada pemenuhan syaratsyarat administrasi, seperti promosi dan pembinaan karir. Salah satu pelatihan dalam pendeteksian kecurangan ialah fraud audit training, yaitu salah satu teknik atau pelatihan agar auditor mampu menginvestigasi dan mendeteksi kecurangan yang ada dalam laporan keuangan perusahaan (Lhaksmi, 2008).

Faktor lain yang mempengaruhi penilaian kecurangan adalah tindakan supervisi. Seorang auditor juga memerlukan suatu tindakan supervisi yang dapat membantunya dalam meningkatkan motivasi dalam bekerja sehingga dapat bekerja dengan baik. Adanya tindakan supervisi dan tumbuhnya motivasi kerja sangat menentukan prestasi kerja (kinerja). Kinerja seringkali identik dengan kemampuan (ability) seorang auditor bahkan berhubungan dengan komitmen terhadap profesi.
Agar setiap internal auditor di KAP dapat melaksanakan tugas utamanya dengan baik diperlukan peranan supervisi dari lini senior auditor yang dimaksud dengan supervisi adalah tindakan mengawasi atau mengarahkan penyelesaian pekerjaan agar terhindar dari suatu yang tidak diinginkan. Seiring dengan perjalanan waktu, supervisi dikatakan sebagai proses yang dinamis.

$\begin{array}{ccc}\text { Penelitian } & \text { mengenai } & \text { pengaruh } \\ \text { tindakan supervisi terhadap } & \text { penilaian }\end{array}$ kecurangan yang sudah dilakukan peneliti sebelumnya , misalnya penelitian yang dilakukan Marietta Sylvie Bolang dan Jenny Morasa (2013) tentang tindakan supervisi, yang menunjukan bahwa tindakan supervise berpengaruh positif terhadap penilaian kecurangan, namum penelitian yang dilakukan Anton Kurniawan, Endar Pituringsih dan Alamsyah (2015) yang menyimpulkan bahwa tindakan supervisi auditor tidak berpengaruh terhadap penilaian kasus kecurangan.

Sampel dalam penelitian ini adalah auditor yang bekerja pada Kantor Akuntan Publik (KAP) KPMG di Jakarta dengan periode penelitian tahun 2017 yang diharapkan dapat memberikan data yang akurat.

\section{Kajian Teoritis dan Hipotesis}

Pengalaman

Audit menuntut keahlian dan profesionalisme yang tinggi. Keahlian tersebut tidak hanya dipengaruhi oleh pendidikan formal saja tetapi banyak faktor lain yang mempengaruhi antara lain adalah pengalaman.. Semakin banyak pengalaman yang diperoleh, maka semakin meningkat pula keahlian yang dimiliki seseorang. Penggunaan pengalaman didasarkan pada asumsi bahwa tugas yang dilakukan secara berulang-ulang memberikan peluang untuk belajar melakukannya dengan yang terbaik. 
Beberapa definisi berikut akan memberikan penjelasan tentang pengalaman itu sendiri, antara lain:

Menurut Sucipto (2007) pengalaman adalah pengetahuan atau keahlian yang diperoleh dari suatu peristiwa melalui pengamatan langsung maupun berpartisipasi dalam peristiwa tersebut. Pengalaman akan mempengaruhi sensitivitas auditor terhadap isyarat-isyarat kecurangan.

\section{Anggriawan (2014) mengatakan bahwa pengalaman akan memberikan pelajaran terhadap jenis dari kecurangan- kecurangan yang pernah ditemukan auditor. Auditor yang berpengalaman menyimpan banyak hal dalam ingatannya sehingga dapat mengembangkan pemahaman yang baik terhadap kasus yang dihadapi.}

Akram, Inapty dan Sukriah (2009), menyatakan bahwa seorang karyawan yang memiliki pengalaman kerja yang tinggi akan memiliki keunggulan dalam beberapa hal diantaranya:

a) Mendeteksi kesalahan

b) Memahami kesalahan

c) Mencari penyebab munculnya kesalahan

Oleh karena itu, auditor yang kurang berpengalaman tentunya akan berbeda dengan yang telah cukup berpengalaman dengan masa masa kerja yang lebih lama dalam pekerjaan dan keputusan audit. Auditor yang kurang berpengalaman akan melakukan tingkat kemungkinan kesalahan yang lebih besar dibandingkan dengan auditor yang berpengalaman.

\section{Pelatihan}

Dalam rangka memenuhi persyaratan sebagai seorang auditor yang profesional, auditor harus menjalani pelatihan yang cukup. Definisi pelatihan menurut Tanjung dan Arep (2002) adalah sebagai berikut :
"Pelatihan merupakan salah satu usaha untuk mengembangkan sumber daya manusia , terutama dalam hal pengetahuan (Knowledge), kemampuan (Ability), dan keahlian (Skill) dan sikap (attitude)."

Pelatihan merupakan bagian dari suatu proses pendidikan yang tujuannya untuk meningkatkan kemampuan dan keterampilan khusus seseorang atau kelompok. Pelatihan adalah suatu proses pendidikan jangka pendek yang menggunakan prosedur sistematis dan terorganisir dimana staf mempelajari pengetahuan dan keterampilan teknis dalam tujuan yang terbatas (Ayuni, 2008)

Berdasarkan pengertian diatas, maka dapat disimpulkan bahwa pelatihan merupakan suatu proses pendidikan jangka pendek guna memperoleh dan mengembangkan pengetahuan dan keterampilan yang khusus agar mampu melakukan sesuatu. Pengetahuan yang harus dimiliki dan didapat oleh auditor tersebut yaitu pengetahuan mengenai hal - hal yang berkatian dengan tindakan kecurangan (Fraud), sehingga fraud yang kerap terjadi dalam suatu organisasi dapat dicegah dan dideteksi keberadaannya.

Pelatihan di bidang fraud auditing merupakan salah satu kegiatan pengembangan auditor untuk meningkatkan kualitas auditnya. Dengan adanya pelatihan ini, diharapkan dapat meningkatkan kinerja dan produktifitas auditor, yang pada akhirnya meningkatkan produktifitas Kantor Akuntan Publik (KAP) secara keseluruhan. Sebaiknya pelatihan dan pengembangan auditor dilakukan secara berkala dan teratur.

\section{Tindakan Supervisi}

Supervisi merupakan hal pendukung yang besar dalam membuat pola pikiran dari seorang auditor untuk menjauhi segala jenis kecurangan yang dimaksud dengan supervisi adalah pengawasan utama, pengontrolan 
tertinggi atau penyeliaan (Kamus Besar Bahasa Indonesia).

Tindakan Supervisi disebutkan dalam Statement on Auditing Standard (SAS) Nomor 22 tentang Standar lapangan pertama berbunyi "the work is to be adequately planned and assistants, if any, are to be properly supervised", Akuntan sebagai pihak yang harus disupervisi di lingkungan Kantor Akuntan Publik (KAP), karena banyak para akuntan yang bekerja tidak sesuai dengan standart yang berlaku sehingga Kantor Akuntan Publik (KAP) sering mengalami ketidakpuasan kerja. Penyebab tidak puas yang dicetuskan oleh (Abercht et al 1981) ini antara lain :

a) Kurangnya pemberian umpan balik (feedback)

b) Kemampuan kurang dimanfaatkan

c) Kurangnya Supervisi

d) Rendahnya kesempatan untuk berpartisipasi

e) Kurangnya pujian untuk pekerjaan yang dilakukan dengan baik

Hal-hal ini bisa menyebabkan kurangnya profesionalisme akuntan dalam melaksanakan tugasnya , sehingga akan berdampak pada pandangan negative dalam melakukan tugasnya seperti kemampuan dalam mendeteksi kecurangan. Sehingga penting sekali tugas senior atau atasan di Kantor Akuntan Publik (KAP) dalam melakukan tindakan supervisi terhadap auditor, khusus nya auditor yang masih belum berpengalaman.

Melakukan tugas dengan baik dibutuhkan keterampilan bukan hanya keterampilan teknis melainkan juga keterampilan dalam supervisi. Dengan supervisi, dapat memberikan inspirasi kepada bawahan untuk bersama-sama menyelesaikan tugas atau pekerjaan dengan jumlah lebih banyak, waktu yang lebih cepat, cara yang lebih mudah dan hasil yang lebih baik daripada jika dikerjakan sendiri. Demikian pula dengan seorang manajer, supervisor atau pemimpin unit, ia harus bisa membawa timnya ke target yang telah ditetapkan. Mendelegasikan sebagian tugas-tugasnya, terutama yang bersifat teknis lapangan kepada auditor pemula akan lebih efektif apabila terdapat keterbatasan waktu dan tenaga. Jadi, apabila tugastugas lainnya perlu didelegasikan kepada anggota tim. "Example is the best policy." Mungkin prinsip inilah yang penting untuk diterapkan dalam melakukan tindakan supervisi. Seringkali kata-kata saja kurang efektif dan sulit untuk dimengerti, maka dalam kondisi seperti ini dibutuhkan suatu tindakan yang tepat seperti memberikan contoh konkret bagaimana bersikap dan bagaimana melakukan tugas agar terhindar dari kasus kecurangan.

Memberikan pengarahan kepada anak buah (auditor pemula) untuk melakukan pekerjaan, seorang supervisor perlu memiliki keterampilan teknis yang cukup yang menyangkut teknis penyelesaian pekerjaan di unit yang terkait. Kebutuhan yang paling penting bagi akuntan yang berkaitan dengan kerja adalah evaluasi secara fair (adil) terhadap dirinya, kemudian kebutuhan kedua yang penting adalah supervisi yang kompeten dan fair.

\section{Penilaian Kecurangan}

Auditor adalah seseorang yang mengemban kepercayaan publik, oleh karena itu, auditor harus memiliki kemampuan yang akan digunakannya dalam melaksanakan tugas audit. Salah satu kemampuan yang harus dimiliki auditor adalah kemampuan untuk mendeteksi kecurangan yang dapat saja terjadi dalam tugas auditnya.

Dalam penelitian ini kemampuan mendeteksi kecurangan berarti proses menemukan atau menentukan suatu tindakan ilegal yang dapat mengakibatkan salah saji dalam pelaporan keuangan yang dilakukan secara sengaja. Cara yang dapat digunakan untuk mendeteksi kecurangan adalah dengan melihat tanda, sinyal, atau red flags suatu tindakan yang diduga menyebabkan atau 
potensial menimbulkan kecurangan. Secara garis besar, tanda-tanda yang digunakan untuk mengindikasikan kecurangan dibagi menjadi dua yaitu tanda-tanda kecurangan yang berasal dari dalam dan luar perusahaan (Eko Ferry Anggriawan , 2014). Tanda-tanda yang berasal dari dalam perusahaan meliputi penyimpangan pemakaian produksi yang ditunjukkan oleh beberapa laporan produksi yang telah diubah, pengubahan catatan untuk menyembunyikan transaksi ilegal, penghilangan catatan-catatan yang dapat membuktikan terjadinya manipulasi, dan lainlain. Sedangkan tanda-tanda kecurangan yang berasal dari luar perusahaan meliputi kelebihan pembebanan jasa dan bahan, tagihan yang salah dikirimkan ke perusahaan yang salah akibat pemalsuan faktur, kekurangan bukti pendukung untuk suatu pembayaran barang dan jasa, dan lain-lain.

Tipe tindakan kecurangan berhubungan dengan gejala-gejala yang dapat digunakan sebagai sinyal adanya kecurangan. Hillison et al. (1999 dalam Marcellina Widiyastuti dan Sugeng Pamudji, 2009) menyampaikan beberapa bentuk sinyal kecurangan, meliputi adanya dokumen yang hilang, adanya pembayaran ganda, adanya jumal yang tidak biasa pada awal atau periode akuntansi, adanya komplain dari pelanggan, adanya pembayaran atau pengeluaran yang tidak masuk akal, dan lain-lain.

Selain dengan melihat tanda atau sinyal terjadinya kecurangan, petunjuk kecurangan lainnya yaitu dengan melihat ada tidaknya red flags. Red flags merupakan suatu kondisi yang janggal atau berbeda dengan keadaan normal. Dengan kata lain, red flags adalah petunjuk atau indikasi akan adanya sesuatu yang tidak biasa dan memerlukan penyidikan lebih lanjut (Sitinjak, 2008). Meskipun timbulnya red flags tidak selalu mengindikasikan adanya kecurangan, namun red flags ini biasanya selalu muncul di setiap kasus kecurangan yang terjadi sehingga dapat menjadi tanda peringatan bahwa kecurangan (fraud) terjadi (Amrizal, 2004). Pemahaman dan analisis lebih lanjut mengenai red flags, dapat membantu langkah selanjutnya untuk memperoleh bukti awal atau mendeteksi adanya kecurangan.

Setelah mengetahui cara untuk mendeteksi kecurangan, seorang auditor, khususnya auditor pemerintah wajib untuk memperhatikan sikap-sikapnya sesuai dengan standar profesinya karena jika tidak diikuti oleh sikap dari auditor itu sendiri, cara tersebut akan menjadi sia-sia. Auditor dapat gagal dalam mendeteksi kecurangan yang terjadi atau bahkan setelah mengetahui adanya kecurangan tersebut, auditor ikut terlibat dalam menyembunyikan kecurangan tersebut. Sikap minimal yang harus dipertahankan auditor sesuai dengan standar umum profesinya, yaitu sikap kompetensi, independensi, dan profesionalisme (SPKN, 2007).

Kompetensi diperlukan agar auditor dapat mendeteksi dengan cepat dan tepat ada tidaknya kecurangan serta trik-trik rekayasa yang dilakukan dalam melakukan kecurangan tersebut karena keahlian yang dimilikinya dapat menjadikannya lebih sensitif (peka) terhadap tindak kecurangan (Lastanti, 2005). Independensi diperlukan agar auditor bebas dari kepentingan dan tekanan pihak manapun, sehingga auditor dapat mendeteksi ada atau tidaknya kecurangan pada perusahaan yang di auditnya dengan tepat, dan setelah kecurangan tersebut terdeteksi, auditor tidak ikut terlibat dalam mengamankan praktik kecurangan tersebut (Lastanti, 2005). Sedangkan profesionalisme diperlukan agar auditor dapat memperoleh keyakinan memadai bahwa laporan keuangan yang di auditnya bebas dari salah saji material, baik yang disebabkan oleh kekeliruan maupun kecurangan.

\section{Hipotesis Penelitian}

$\mathrm{H}_{\mathrm{a} 1}$ : Pengalaman Auditor berpengaruh positif terhadap Pendeteksian Kecurangan.

$\mathrm{H}_{\mathrm{a} 2}$ : Pelatihan Auditor berpengaruh positif terhadap Pendeteksian Kecurangan. 
$\mathrm{H}_{\mathrm{a} 3:}$ Tindakan Supervisi berpengaruh positif terhadap Pendeteksian Kecurangan.

\section{Metode Penelitian}

Objek dalam penelitian ini adalah para auditor yang bekerja pada salah satu Kantor Akuntan Publik (KAP) big four di Jakarta dengan periode penelitian tahun 2017. Untuk memperoleh data yang diperlukan dalam penulisan skripsi ini, teknik pengumpulan data yang digunakan penulis adalah metode survei dengan kuesioner. Kuesioner yang dibagikan penulis melibatkan 60 responden.

Teknik pengambilan sampel yang digunakan penulis adalah randomsampling, dimana penentuan sampel penelitian dilakukan dengan beberapa pertimbangan tertentu yang bertujuan agar data yang diperoleh nantinya bisa lebih representatif.

Program komputer yang digunakan oleh penulis dalam mengelolah data yang diperoleh adalahIBM SPSS Statistics 20.0.Teknik analisis data yang digunakan dalam penelitian ini adalah sebagai berikut:

\section{Uji Skala Likert}

kala yang dipakai dalam penyusunan kuesioner adalah skala ordinal atau sering disebut skala likert, yaitu skala yang berisi lima tingkat preferensi jawaban dengan pilihan sebagai berikut;

\begin{tabular}{ll}
\hline Skor & Pendapat \\
\hline 1 & Sangat Tidak Setuju \\
2 & Tidak Setuju \\
3 & Ragu-ragu atau Netral \\
4 & Setuju \\
5 & Sangat Setuju \\
\hline
\end{tabular}

2. Uji Kualitas Data
Di dalam pengujian kualitas data terdiri dari uji validitas dan uji reliabilitas, penulis akan melakukan uji validitas dan uji reliabilitas sebanyak dua kali. Yang pertama akan dilakukan pra-kuesioner kepada sampel 30 responden. Jika semua butir pertanyaan dinyatakan valid dan reliabel, maka seluruh butir pertanyaan dapat digunakan untuk tahap kedua, yaitu pengumpulan data kuesioner kepada 100 responden.

3. Uji Asumsi Klasik

Pengujian model regresi dalam menguji hipotesis haruslah menghindari kemungkinan terjadinya penyimpangan asumsi klasik. Uji asumsi klasik yang akan diuji adalah uji normalitas, uji multikolinieritas,dan uji heteroskedastisitas

4. Uji Hipotesis

Uji hipotesis pada penelitian ini menggunakan analisis regresi berganda. Analisis ini bertujuan untuk mengukur kekuatan antara dua variabel atau lebih (variabel independen terhadap variabel dependen). Persamaan regresi berganda dirumuskan:

$$
\begin{array}{ll}
\mathbf{P K}=\boldsymbol{\alpha}+\boldsymbol{\beta}_{\mathbf{1}} \mathbf{P G L}+\boldsymbol{\beta}_{2} \mathbf{P L T}+\boldsymbol{\beta}_{\mathbf{3}} \mathbf{T S V}+\boldsymbol{\varepsilon} \\
\text { Keterangan: } \\
\hline \text { PK } & \text { : Penilaian Kecurangan } \\
\alpha & : \text { Konstanta Regresi } \\
\beta 1, \beta 2, & \beta 3: \text { Koefisien Regresi } \\
\text { PGL } & : \text { Pengalaman Auditor } \\
\text { PLT } & : \text { Pelatihan Auditor } \\
\text { TSV } & : \text { Tindakan Supervisi Auditor } \\
\varepsilon & : \text { Error }
\end{array}
$$

Uji hipotesis yang digunakan dalam penelitian ini adalah koefisien determinasi, uji $\mathrm{F}$, dan uji t.

\section{Hasil Penelitian}




\section{Uji Kualitas Data}

Uji Validitas

Uji validitas dilihat dengan membandingkan antara $r$ hitung dengan $r$ tabel. Jika rhitung $>\mathrm{r}$ tabel, maka dapat dikatakan valid, dimana $r$ tabel untuk $n=30$ adalah 0,3061. Berdasarkan hasil pengolahan data yang terlihat pada tabel 1 didapatkan nilai untuk variabel pengalaman auditor nilai terkecilnya 0,848 , variabelpelatihan auditor nilai terkecilnya 0,787 , variable tindakan supervise nilai terkecilnya 0,761 dan variabel penilaian kecurangan nilai terkecilnya 0,793 . Hasil ini membuktikan bahwa setiap butir dari pertanyaan di kuesioner adalah valid.

Uji Reliabilitas

Dalam penelitian ini, penulis menggunakan Cronbach Alpha $(\alpha)$ untuk melakukan uji reliabilitas. Setelah mendapatkan Cronbach Alpha ( $\alpha$ ), maka penulis akan membandingkan dengan nilai standar output alpha yaitu sebesar 0,70. Keandalan konsistensi antar item atau koefisien keandalan Cronbach Alpha dapat dilihat pada tabel 2 dimana untuk variabel pengalaman auditor sebesar 0,850 , variabel pelatihan auditor sebesar 0,799 , variabel tindakan supervise sebesar 0,713 dan variabel penilaian kecurangan sebesar 0,722 . Data ini menunjukkan bahwa setiap variabel memiliki indeks reliabilitas yang lebih tinggi daripada 0,700 yang berarti semua variabel adalah reliabel.

\section{Statistik Deskriptif}

Variabel yang digunakan dalam statistik deskriptif ini meliputi Pengalaman Auditor Pelatihan Auditor , Tindakan Supervisi auditor dan kecurangan audit seperti yang dilihat pada tabel 3 dimana pada variabel pengalaman auditor memiliki rata rata total jawaban 4.11 artinya rata - rata jawaban setuju, rata rata variabel pelatihan auditor 4.10 artinya rata - rata jawaban setuju, rata rata variabel supervisi auditor 4 artinya rata - rata setuju dan rata rata variabel Penilaian Kecurangan 3.97 yang artinya rata -rata ragu ragu

\section{Uji Asumsi Klasik}

Uji Normalitas

Uji normalitas dilakukan untuk mengetahui apakah data dari model regresi berdistribusi normal atau tidak. Uji normalitas data dalam penelitian ini menggunakan uji Kolmogorov-Smirnov dengan tingkat signifikansi lebih besar dari 5\%, maka dapat dikatakan bahwa variabel tersebut berdistribusi normal.Dari hasil uji normalitas pada tabel 4 dengan uji Kolmogorov-Smirnov menunjukkan bahwa nilai signifikansi 0,000 . Nilai signifikansi tersebut lebih kecil dari 0,05 sehingga menunjukkan bahwa data pada model tersebut tidak berdistribusi normal, namun menurut The Central Limit Theorem dalam Widya dan Sandra (2014) mengatakan bahwa jika ukuran sampel setidaknya berjumlah tiga puluh sampel, berarti sampel dari populasi tersebut telah terdistribusi normal.

\section{Uji Multikolinieritas}

Uji multikolinieritas bertujuan untuk menguji apakah dalam model regresi ditemukan adanya korelasi antar variabel bebas (variabel independen). Multikolinieritas dapat dilakukan dengan melihat nilai TOL (Tolerance) dan VIF (Varian Inflation Factor) dari masing-masing variabel bebas terhadap variabel terikatnya. Dari hasil uji multikolinieritas pada tabel 5 menunjukkan bahwa nilai tolerance lebih dari 0,10 dan nilai VIF kurang dari 10 maka dalam model regresi ini dapat ditarik kesimpulan antara variabel independen yang terdapat dalam model menunjukan tidak adanya multikolinearitas.

Uji Heteroskedastisitas

Uji heteroskedastisitas bertujuan untuk menguji apakah dalam model regresi 
terjadi ketidaksamaan varians dari residual satu pengamatan ke pengamatan yang lain. Model regresi yang baik adalah homokedastisitas atau tidak terjadi adanya heteroskedastisitas. Cara yang digunakan untuk mendeteksi heteroskedastisitas adalah dengan menggunakan uji statistik Spearman's Rho.Berdasarkan hasil uji statistik Spearman's Rho pada tabel 6, dapat ditemukan bahwa dalam hasil penelitian ini untuk variabel independen lebih besar dari 0,05 sehingga menunjukkan bahwa tidak terjadi heteroskedastisitas.

\section{Uji Hipotesis}

Uji Koefisien Determinasi $\left(\mathrm{R}^{2}\right)$

Uji koefisien determinasi (R2) pada intinya mengukur seberapa jauh kemampuan model menerangkan variabel independen. Nilai koefisien determinasi adalah antara nol dan satu. Dari hasil uji koefisien determinasi pada tabel 7 menunjukkan bahwa besarnya Adjusted $R$ Square pada model summary adalah 0,409 yang berarti 40,9\% variasi penilaian kecurangan dijelaskan oleh variabel independen yaitu pengalaman, pelatihan dan tindakan supervisi, sedangkan sisanya yaitu sebesar $59,1 \%$ dijelaskan oleh faktor-faktor lain di luar model penelitian ini.

\section{Uji F}

Uji keberartian model dilakukan melalui uji $\mathrm{F}$ dengan membandingkan nilai $\mathrm{F}$ dan signifikansi hasil $\mathrm{F}$ tabel.Nilai signifikansi dari tabel 8 menunjukkan adanya nilai yang signifikan. Oleh karena itu, menunjukkan adanya hubungan antara variabel independen dengan variabel dependen yang signifikan. Sehingga dapat ditarik kesimpulan bahwa terdapat cukup bukti bahwa variabel independen yaitu pengalaman, pelatihan dan tindakan supervisi secara bersama-sama berpengaruh secara signifikan terhadap variabel dependen yaitu penilaian kecurangan.

Uji t

Persamaan regresi linier berganda dalam penelitian ini didapatkan sebagai berikut:

$$
\mathrm{PK}=1,618+0,704 \mathrm{PGL}+0,032 \mathrm{PLT}+0,104 \mathrm{TSV}
$$

Dari persamaan di atas dapat diketahui bahwa konstanta sebesar 1,618 menyatakan bahwa variabel independen dianggap konstan, maka rata-rata penilaian kecurangan sebesar 1,618. Koefisien regresi pengalaman auditor sebesar 0,704 menyatakan bahwa setiap kenaikan faktor pengalaman auditor (X1) akan menambah sebesar 0,704 penilaian kecurangan (Y) , koefisien regresi pelatihan auditor sebesar 0,032 menyatakan bahwa setiap kenaikan faktor pelatihan auditor (X2) akan menambah sebesar 0,032 penilaian kecurangan (Y). Koefisien regresi tindakan supervisi sebesar 0,104 menyatakan bahwa setiap kenaikan faktor tindakan supervise (X3) akan menambah 0,104 penilaian kecurangan $(\mathrm{Y})$

Dalam tabel 9 dapat dilihat nilai signifikansi tiap-tiap variabel dimana nilai signifikansi yang dipakai adalah $\alpha=5 \%$. Berdasarkan hasil uji di atas menunjukkan bahwa variabel pengalaman, pelatihan dan tindakan supervisi auditor memberikan pengaruh yang signifikan terhadap variabel penilaian kecurangan karena nilai signifikansi tiap-tiap variabel < 0,05 yaitu untuk pengalaman auditor sebesar 0,000, untuk pelatihan auditor sebesar 0,022 dan untuk tindakan supervisi sebesar 0,017. Sehingga dapat disimpulkan, pengalaman , pelatihan dan tindakan supervisi auditor memberikan pengaruh terhadap penilaian kecurangan.

\section{Pembahasan}


Berdasarkan hasil analisis yang dilakukan pada penelitian ini, maka hasil penelitian yang diperoleh sebagai berikut:

1. Pengalaman Auditor

Pengaruh variabel pengalaman auditor dapat dilihat dari uji $\mathrm{t}$ dengan nilai signifikansi 0,000 yang menunjukkan bahwa nilai signifikansi tersebut $<0,05$. Hal ini menyatakan, pengalaman auditor berpengaruh positif terhadap penilaian kecurangan. Adapun besarnya hubungan variabel terikat (penilaian kecurangan) yang bisa dijelaskan oleh variabel bebas (pengalaman, pelatihan dan tindakan supervisi auditor) sebesar 40,9\% yang dapat dilihat dari nilai Adjusted $R$ Square.

Pengalaman auditor sangat berpengaruh terhadap penilaian kecurangan. Pengalaman yang dimiliki oleh auditor akan sangat membantu auditor dalam melaksanakan pekerjaan. Auditor yang berpengalaman tidak hanya memiliki kemampuan untuk menemukan kecurangan tetapi juga auditor tersebut dapat memberikan penjelasan yang lebih akurat dibanding auditor yang kurang pengalaman.

Hal ini juga sejalan dengan penelitian yang dilakukan oleh Noviyani dan Bandi (2002) menyatakan bahwa adanya hubungan positif antara pengalaman auditor dengan pendeteksian kecurangan. Semakin berpengalaman auditor maka akan semakin tinggi tingkat pendeteksian kecurangan. Auditor yang berpengalaman juga akan lebih paham terkait penyebab kekeliruan yang terjadi, apakah karena murni kesalahan baik manusia atau alat ataukah kekeliruan karena kesengajaan yang berarti fraud.

2. Pelatihan Auditor

Pengaruh variabel pengalaman auditor dapat dilihat dari uji t dengan nilai signifikansi 0,044 yang menunjukkan bahwa nilai signifikansi tersebut $<0,05$. Hal ini menyatakan, pengalaman auditor berpengaruh positif terhadap penilaian kecurangan. Adapun besarnya hubungan variabel terikat (penilaian kecurangan) yang bisa dijelaskan oleh variabel bebas (pengetahuan dan pengalaman auditor) sebesar $40.9 \%$ yang dapat dilihat dari nilai Adjusted R Square.

Pelatihan auditor sangat berpengaruh terhadap penilaian kecurangan. Seorang auditor yang memiliki latihan yang banyak, tingkat pendidikan yang tinggi, serta ilmu dan pelatihan yang dimiliki selama menjadi auditor merupakan dasar yang digunakan dalam melakukan audit untuk melacak adanya temuan kecurangan. Tingkat pelatihan yang dimiliki auditor merupakan hal yang sangat penting yang dapat mempengaruhi auditor dalam mengambil keputusan.

Hasil penelitian ini juga konsisten dengan hasil penelitian sebelumnya yang dilakukan oleh Lhaksmi (2008) yang menyatakan bahwa seorang auditor yang memiliki frekuensi pelatihan yang banyak akan memiliki kematangan dan keterampilan dalam melaksanakan tugas auditnya sehingga dapat mendeteksi fraud.

3. Tindakan Supervisi

Pengaruh variabel pengalaman auditor dapat dilihat dari uji t dengan nilai signifikansi 0,034 yang menunjukkan bahwa nilai signifikansi tersebut $<0,05$. Hal ini menyatakan, pengalaman auditor berpengaruh positif terhadap penilaian kecurangan. Adapun besarnya hubungan variabel terikat (penilaian kecurangan) yang bisa dijelaskan oleh variabel bebas (pengetahuan dan pengalaman auditor) sebesar $40,9 \%$ yang dapat dilihat dari nilai Adjusted R Square.

Hasil penelitian ini konsisten dengan penelitian sebelumnya yang dilakukan oleh Jenny Morasa (2013) yaitu dimana tingkat arah dan bimbingan supervisi yang dilakukan atasan kepada bawahan akan meningkatkan kualitasnya , karena dengan jenjang arahan yang memadai dan 
konsisten akan meningkatkan wawasan serta kemampuan seorang auditor untuk memegang tanggung jawab dalam menjalankan tugasnya.

\section{Simpulan}

Berdasarkan data yang diperoleh dan hasil analisis yang dilakukan pada penelitian ini, maka dapat disimpulkan sebagai berikut:

1. Terbukti bahwa variabel Pengalaman berpengaruh positif terhadap penilaian kecurangan

2. Terbukti bahwa variabel Pelatihan berpengaruh positif terhadap Penilaian kecurangan.

3. Terbukti bahwa variabel tindakan supervise berpengaruh positif terhadap penilaian kecurangan.

\section{Saran}

Dalam proses penelitian ini, peneliti memiliki keterbatasan, yaitu jumlah sampel yang digunakan dan penggunaan variabel independen dalam penelitian ini. Untuk itu, saran yang dapat diberikan bahwa:

Peneliti selanjutnya yang ingin melakukan penelitian serupa, sebaiknya memperluas populasi penelitian. Populasi penelitian tidak hanya diambil dari kantor akuntan publik KPMG saja.

Penelitian selanjutnya hendaknya memilih variabel yang lebih baru dan belum pernah digunakan dalam penelitian lainya yang dapat mempengaruhi penilaian kecurangan.

Penelitian selanjutnya diharapkan tidak hanya menggunakan data yang berasal dari survei melalui kuisioner saja, tetapi perlu menambah informasi yang relevan berdasar wawancara atau dokumen langsung dalam kegiatan lapangan KAP.

\section{Daftar Pustaka}

Amrizal. 2004. Pencegahan dan Pendeteksian Kecurangan Oleh Auditor Internal.

Anggriawan, E. F. 2014. Pengaruh Pengalaman Kerja, Skeptisme Profesional dan Tekanan Waktu Terhadap Kemampuan Auditor Dalam Mendeteksi Fraud (Studi Empiris Pada Kantor Akuntan Publik Di DIY). Jurnal Nominal/Volume III Nomor 2/Tahun 2014.

Cooper, Donald R. dan Pamela S. Schindler. 2017. Metode Penelitian Bisnis. Edisi 12. (Buku 1). Jakarta: Salemba Empat.

Ghozali, I. 2016. Aplikasi Analisis Multivariate Dengan Program IBM SPSS 23. Semarang: Badan Penerbit Universitas Diponegoro.

Anggriawan. 2014. Pengalaman akan Memberikan Pelajaran Terhadap Jenis dari Kecurangan-Kecurangan

Kurniawan, Anton., Endar Pituringsih dan Alamsyah. 2015. Pengetahuan, Pengalaman, Pelatihan Profesional, dan Tindakan Supervisi Dalam Mendeteksi Kecurangan (Studi Empiris pada Inspektorat Provinsi NTB dan Kabupaten/Kota se-Pulau Lombok). Jurnal Akuntansi Aktual, Vol. 3, Nomor 1, Januari 2015, hlm. 11-21.

Karim dan Lhaksmi 2008 Pengaruh Pendidikan , Pelatihan dan Pengalaman Terhadap Mendeteksi Kecurangan.

Mulyadi. 1992. Pemeriksaan Akuntansi. Edisi 4. Yogyakarta: BP-STIE YKPN.

Noviyani, Putri dan Bandi. 2002. Pengaruh Pengalaman dan Pelatihan Terhadap Struktur Pengetahuan Auditor Tentang Kekeliruan. 
Purnamasari, Dina dan Erna Hernawati. 2013. Pengaruh Etika Auditor, Pengalaman, Pengetahuan dan Perilaku Disfungsional Terhadap Kualitas Audit. Jurnal NeO-Bis, Volume 7, Nomor 2, Desember 2013.

Refleksi untuk Profesi Auditor atas Kasus KPMG. 2017, Oktober 10). Retrieved from WartaEkonomi.co.id: https://www.wartaekonomi.co.id/read 154644/refleksi-untuk-profesiauditor-atas-kasus-kpmg-danpwc.html

Sucipto 2007. Pengaruh Independensi, Pengalaman, Due Professional Care dan Akuntabilitas Terhadap Kualitas Audit. Simposium Nasional Akuntansi XIII, Purwokerto 2010.

Sugiyono. 2015. Metode Penelitian (Pendekatan Kuantitatif, Kualitatif dan $R \& D)$. Bandung: Alfabeta.

Marietta Sylvie Bolang dan Jenny Morasa 2013. Pengaruh Tindakan Supervisi dan Pelatihan auditor Terhadap Pendeteksian kecurangan pada perusahaan.

Tim Penyusun Standar Pemeriksaan Keuangan Negara (SPKN). 2007. Standar Pemeriksaan Keuangan Negara. Jakarta: Badan Pemeriksa Keuangan Republik Indonesia.
Widiyastuti, Marcellina dan Sugeng Pamudji. 2009. Pengaruh Kompetensi, Independensi dan Profesionalisme Terhadap Kemampuan Auditor Dalam Mendeteksi Kecurangan (Fraud). Value Added, Vol. 5, No. 2, Maret 2009 - Agustus 2009.

Statement on Auditing Standard (SAS) Nomor 22 tentang Standar lapangan pertama dalam Pengaruh tindakan Supervisi terhadap auditor pemula

Tanjung dan Arep. 2002. Analis Pengaruh Pengalaman dan Pelatihan Auditor Terhadap Pengetahuan Auditor Dalam Mentdeteksi Kecurangan. Jurnal Inovasi dan Kewirausahaan, Volume 4, No. 1, Januari 2015, Halaman 1-8.

KPMG facing problem rolls royce bribery revelation. 2017, Oktober 10). Retrieved from dailymail.co.uk: http://www.dailymail.co.uk/news/arti cle-4150212/KPMG-facing-probeRolls-Royce-bribery-revelation.html

Kasus fraud audit pada bank BRI . 2015, Juni 17). Retrieved from Kompasiana.com: https://www.kompasiana.com/ema_su rya/kasus-fraud-audit-pada-bankbri_556c4a38c823bdd4038b456f 
Lampiran

Tabel 1

Uji Validitas

\begin{tabular}{ccccc}
\hline No & Variabel & Pertanyaan & r hitung & Keterangan \\
\hline $1 \quad$ Pengalaman & 1 & 0,848 & Valid \\
& Auditor & 2 & 0,931 & Valid \\
& & 3 & 0,856 & Valid \\
& Pelatihan & 1 & 0,787 & Valid \\
& Auditor & 2 & 0,904 & Valid \\
& & 3 & 0,890 & Valid \\
& Tindakan & 1 & 0,761 & Valid \\
& Supervisi & 2 & 0,825 & Valid \\
& & 3 & 0,841 & Valid \\
& & 1 & 0,793 & Valid \\
& Penilaian & 2 & 0,809 & Valid \\
& Kecurangan & 3 & 0,822 & Valid \\
\hline
\end{tabular}

Sumber: Hasil Pengolahan Data Penelitian (Lampiran Output SPSS)

] 
Tabel 2

Uji Reliabilitas

\begin{tabular}{lcccc}
\hline No & Variabel & Cronbach & $\begin{array}{c}\text { Sandar } \\
\text { Output } \\
\text { Alpha }(\boldsymbol{\alpha})\end{array}$ & Keterangan \\
\hline $1 \quad$ & $\begin{array}{c}\text { Pengalaman } \\
\text { Auditor }\end{array}$ & 0,850 & 0,700 & Reliabel \\
\hline & $\begin{array}{c}\text { Pelatihan } \\
\text { Auditor }\end{array}$ & 0,799 & 0,700 & Reliabel \\
& $\begin{array}{c}\text { Tindakan } \\
\text { Supervisi }\end{array}$ & 0,713 & 0,700 & Reliabel \\
4 & $\begin{array}{c}\text { Penilaian } \\
\text { Kecurangan }\end{array}$ & 0,722 & 0,700 & Reliabel \\
\hline
\end{tabular}

Sumber: Hasil Pengolahan Data Penelitian (Lampiran Output SPSS)

Tabel 3

Statistik Deskriptif

\begin{tabular}{cccc}
\hline Variabel & Minimum & Maximum & Mean \\
\hline $\begin{array}{c}\text { Pengalaman } \\
\text { Auditor } \\
\text { Pelatihan } \\
\text { Auditor }\end{array}$ & 3 & 5 & 4.11 \\
Tindakan & 3 & 5 & 4.10 \\
$\begin{array}{c}\text { Supervisi } \\
\text { Penilaian } \\
\text { Kecurangan }\end{array}$ & 3 & 5 & 4 \\
\hline Sumbera & 3 & 5 & 3.97
\end{tabular}

Sumber:Data Primer yang diolah 
Tabel 4

Hasil Uji Normalitas

Coefficients $^{\mathbf{a}}$

One-Sample Kolmogorov-Smirnov Test

\begin{tabular}{|ll|r|}
\hline & & $\begin{array}{r}\text { Unstandardized } \\
\text { Residual }\end{array}$ \\
\hline $\mathrm{N}$ & Mean & 100 \\
Normal Parameters $\mathrm{a}, \mathrm{b}$ & Std. Deviation & 2.97558827 \\
& Absolute & .050 \\
Most Extreme Differences & Positive & .038 \\
& Negative & -.050 \\
Kolmogorov-Smirnov Z & & 2.129 \\
Asymp. Sig. (2-tailed) & & .000 \\
\hline
\end{tabular}

a. Test distribution is Normal.

b. Calculated from data

Tabel 5

Hasil Uji Multikolonieritas

Coefficients $^{\mathbf{a}}$

Coefficients $^{a}$

\begin{tabular}{|l|r|r|}
\hline Model & \multicolumn{2}{|c|}{ Collinearity Statistics } \\
\cline { 3 - 4 } & \multicolumn{1}{|c|}{ Tolerance } & VIF \\
\hline \multirow{2}{*}{$\begin{array}{l}\text { (Constant) } \\
\text { Pengalaman }\end{array}$} &, 862 & 1,160 \\
Pelatihan &, 971 & 1,030 \\
Supervisi &, 848 & 1,179 \\
\hline
\end{tabular}

a. Dependent Variable: Kasus Kecurangan 
Tabel 6

Hasil Uji Heteroskedastisitas

\begin{tabular}{|c|c|c|c|c|c|}
\hline \multicolumn{6}{|c|}{ Correlations } \\
\hline & & $\mathrm{X} 1$ & $\mathrm{X} 2$ & X3 & ABS_RES \\
\hline \multirow{12}{*}{$\begin{array}{l}\text { Spearman's } \\
\text { rho }\end{array}$} & Correlation Coefficient & 1.000 & -.042 & .180 & $.358^{* *}$ \\
\hline & Sig. (1-tailed) & . & .376 & .085 & .002 \\
\hline & $\mathrm{N}$ & 60 & 60 & 60 & 60 \\
\hline & Correlation Coefficient & -.042 & 1.000 & .035 & .137 \\
\hline & Sig. (1-tailed) & .376 & . & .394 & .148 \\
\hline & $\mathrm{N}$ & 60 & 60 & 60 & 60 \\
\hline & Correlation Coefficient & .180 & .035 & 1.000 & .185 \\
\hline & Sig. (1-tailed) & .085 & .394 & . & .079 \\
\hline & $\mathrm{N}$ & 60 & 60 & 60 & 60 \\
\hline & Correlation Coefficient & $.358^{* *}$ & -.137 & .185 & 1.000 \\
\hline & Sig. (1-tailed) & .002 & .148 & .079 & \\
\hline & $\mathrm{N}$ & 60 & 60 & 60 & 60 \\
\hline
\end{tabular}

Tabel 7

Hasil Uji Koefisien Determinasi $\left(\mathbf{R}^{2}\right)$

Model Summaryb

\begin{tabular}{|l|r|r|r|r|}
\hline Model & $\mathrm{R}$ & R Square & \multicolumn{1}{|c|}{$\begin{array}{l}\text { Adjusted R } \\
\text { Square }\end{array}$} & $\begin{array}{l}\text { Std. Error of the } \\
\text { Estimate }\end{array}$ \\
\hline 1 & $.639^{\mathrm{a}}$ & .409 & .377 & .901 \\
\hline
\end{tabular}

a. Predictors: (Constant), X3, X2, X1

b. Dependent Variable: $Y$ 
Tabel 8

Hasil Uji F

\begin{tabular}{|c|c|c|c|c|c|}
\hline \multirow[t]{2}{*}{ Model } & \multicolumn{2}{|c|}{ Unstandardized Coefficients } & \multirow{2}{*}{$\begin{array}{l}\text { Standardized } \\
\text { Coefficients } \\
\text { Beta }\end{array}$} & \multirow[t]{2}{*}{$\mathrm{t}$} & \multirow[t]{2}{*}{ Sig. } \\
\hline & $B$ & Std. Error & & & \\
\hline (Constant) & 1.618 & 2.151 & & .752 & .455 \\
\hline pengalaman & .704 & .130 & .059 & 5.413 & .000 \\
\hline pelatihan & .032 & .111 & .030 & .289 & .044 \\
\hline supervisi & .104 & .121 & .096 & .859 & .034 \\
\hline
\end{tabular}

a. Dependent Variable: penilaian kecurangan

b. Predictors: (Constant), supervisi, pelatihan, pengalaman

Tabel 9

Hasil Uji t

ANOVA $^{a}$

\begin{tabular}{|l|r|r|r|r|r|}
\hline Model & Sum of Squares & df & Mean Square & F & \multicolumn{1}{l|}{ Sig. } \\
\hline Regression & 31.478 & 3 & 10.493 & 12.912 &, $000^{\mathrm{b}}$ \\
1 Residual & 45.505 & 56 & .813 & \\
Total & 76,983 & 59 & & & \\
\hline
\end{tabular}

